\title{
Mendukung Transformasi Digital melalui Penyusunan Program Studi Software Engineering
}

\section{Arum Marwati ${ }^{*}$, Ade Wahyudin ${ }^{2}$, Ardian Setio Utomo ${ }^{3}$, Noor Iza ${ }^{4}$, Elfa Nuzila}

\section{Halwa $^{5}$}

1,2,3,4,5 Sekolah Tinggi Multi Media, Yogyakarta, Indonesia

\section{A R T I C L E I N F O}

Article history:

Received July 04, 2021

Revised July 07, 2021

Accepted September 07, 2021

Available online October 25, 2021

Kata Kunci:

STMM, Software Engineering, Program Studi Baru

Keywords:

STMM, Software Engineering, New Study Program

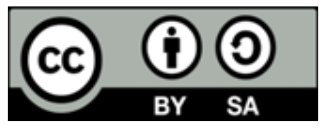

This is an open access article under the CC BY-SA license.

Copyright $(2021$ by Author. Published by Universitas Pendidikan Ganesha.

\begin{abstract}
A B S T R A K
STMM sebagai institusi di bidang perguruan tinggi memiliki peran dalam menjawab tantangan tersebut dengan menghasilkan lulusan-lulusan yang cakap dan unggul di bidang digital. Tujuan penelitian ini untuk dapat menyusun program studi baru yang dapat menghasilkan SDM unggul di bidang digital. Penelitian ini dilakukan dengan pendekatan kualitatif deskriptif menggunakan studi kasus. Penelitian dilakukan dengan beberapa tahap, yaitu: analisis pasar, analisis kebutuhan industri, analisis internal STMM, penyusunan prodi baru hasil yang sesuai dengan Kerangka Kualifikasi Nasional Indonesia (KKNI) dan Standar Nasional Pendidikan Tinggi (SNPT) dilanjutkan dengan analisis kebutuhan sarana dan prasarana prodi baru. Kajian ini dilakukan dengan desk research dan focus group discussion dengan pimpinan dan para dosen. Data yang telah terkumpul dianalisis menggunakan analisis kualitatif deskriptif. Hasil penelitian ini adalah analisis awal untuk menyusun pembentukan program studi baru di STMM Yogyakarta. Kajian ini berisi visi dan misi, tujuan, sasaran, profil lulusan, standar kompetensi lulusan, bahan kajian, dan materi pembelajaran prodi baru. Hasil penelitian dapat menjadi bahan kajian untuk meningkatkan peran STMM dalam memenuhi kebutuhan SDM yang terampil digital. Implikasi penelitian ini adalah Program studi Software Engineering diharapkan mampu mencetak SDM yang memiliki keterampilan digital dan berkontribusi untuk pembangunan Indonesia maupun global agar potensi digital Indonesia tidak tertinggal.
\end{abstract}

\begin{abstract}
A B S T R A C T
STMM as an institution in the field of higher education has a role in responding to these challenges, by producing graduates who are capable and excel in the digital field. The purpose of this research is to be able to develop a new study program that can produce superior human resources in the digital field. This research was conducted with a descriptive qualitative approach using case studies. The research was carried out in several stages, namely: market analysis, industrial needs analysis, STMM internal analysis, preparation of new study programs results in accordance with the Indonesian National Qualifications Framework (KKNI) and National Higher Education Standards (SNPT), followed by analysis of the needs for facilities and infrastructure for study programs. new. This study was conducted using desk research and focus group discussions with leaders and lecturers. The data that has been collected was analyzed using descriptive qualitative analysis. The result of this research is the initial analysis to arrange the formation of a new study program at STMM Yogyakarta. This study contains the vision and mission, goals, objectives, graduate profiles, graduate competency standards, study materials and learning materials for new study programs. The results of the study can be used as study material to increase the role of STMM in meeting the needs of digitally skilled human resources. The implication of this research is that the Software Engineering study program is expected to be able to produce human resources who have digital skills and contribute to Indonesian and global development so that Indonesia's digital potential is not left behind.
\end{abstract}




\section{PENDAHULUAN}

Era revolusi industri 4.0 saat ini mengubah gaya hidup masyarakat, terutama pada pemanfaatan teknologi informasi (Danuri, 2019; Risdianto, 2019). Perkembangan teknologi informasi saat ini sudah mulai merambah ke berbagai bidang kehidupan dan tidak dapat dipungkiri bahwa teknologi informasi dapat meningkatkan efektivitas dan efisiensi kerja suatu organisasi. Meningkatnya pemanfaatan teknologi informasi juga diimbangi dengan kebutuhan sumber daya manusia (SDM) yang mampu dan cakap dalam bidang digital (Astini, Sari, 2020; Latip, 2020). Kebutuhan SDM yang tinggi di bidang teknologi informasi sejalan dengan makin banyak perusahaan yang bertransformasi ke arah digital. Transformasi digital merupakan proses perubahan yang dirancang dan dijalankan secara aktif yang dipengaruhi oleh teknologi digital (Widnyani \& Astitiani, 2021; Zaoui, Fadwa, \& Souissi., 2020). Terjadinya transformasi digital didorng oleh adanya perubahan serta perkembangan teknologi pada organisasi dan lingkungan. Dalam bidang pendidikan, transformasi digital dapat diwujudkan melalui program pengajaran yang berpusat pada siswa. Konsep transformasi pendidikan mendukung keterampilan seperti pembelajaran kolaboratif dan kreatif. Adanya transformasi digital, pengajar menjadi lebih tepat untuk menerapkan kegiatan belajar mengajar, analisis, dan sintesis untuk siswa (Astini, Sari, 2020; Balyer \& Oz, 2018). Dengan adanya transformasi digital diharapkan mampu memberikan kemudahan bagi peserta didik maupun pendidik untuk memperoleh informasi sebagai sumber belajar, sehingga dapat meningkatkan hasil belajar, kreativitas, serta motivasi guna mencapai tujuan dari pendidikan.

Namun yang terjadi di lapangan, perkembangan era digital Indonesia masih panjang karena infrastruktur teknologi informasi dan penggunaan digital masih belum merata (Das, Gryseels, Sudhir, \& Tan, 2016; Raibowo \& Nopiyanto, 2020; Tegeh, Simamora, \& Dwipayana, 2019). Hal ini mengakibatkan Indonesia tertinggal dari pasar terpilih lainnya dalam menangkap potensi digital. Employment Outlook dari riset OECD pada tahun 2019 menunjukan bahwa 60 persen dari pekerja belum memiliki keterampilan digital dasar saat operasional berbagai industri bertransisi menjadi digital (OECD, 2020). Sementara itu, pada peluncuran empat modul literasi digital yang digelar di Grand City Surabaya bulan Mei tahun 2021, Johnny G. Plate selaku Menteri Kominfo menyatakan bahwa Indonesia membutuhkan sembilan juta talenta digital dalam 15 tahun mendatang atau rata-rata sebanyak 600.000 talenta digital per tahun (Sasongko, 2021). Permasalahan kurangnya talenta digital telah menjadi sorotan penting di Indonesia. Presiden Republik Indonesia, Joko Widodo menyatakan bahwa Indonesia butuh lebih banyak talenta digital seperti software engineer, product designer, dan content creator. Pengembangan sumber daya manusia dalam bidang teknologi informasi tidak bisa ditunda. Untuk melakukan hal ini harus dilakukan secara bersama-sama, mulai dari sektor pemerintah, perguruan tinggi negeri maupun swasta (C.Verhoef et al., 2021; Pertiwi, 2020). Joko Widodo memberi penekanan bahwa perguruan tinggi menjadi penentu dalam mencetak tenaga ahli untuk mewujudkan sumber daya manusia yang kompeten pada bidang teknologi perangkat lunak.

Perguruan tinggi di bawah Kementerian Komunikasi dan Informatika, Sekolah Tinggi Multi Media (STMM) dapat berkontribusi untuk mencetak lulusan yang memiliki talenta digital di era 4.0. Kementerian Komunikasi dan Informatika Republik Indonesia, Johnny Gerard Plate dalam rapat kerja bersama DPR RI menyatakan bahwa STMM akan dikembangkan menjadi Institut Digital Nasional pada 2022 (Mawangi, 2021). STMM memiliki tanggung jawab dalam menjawab tantangan tersebut. STMM dalam penyelenggaraan pendidikannya dapat menghasilkan lulusan yang dapat memenuhi kebutuhan SDM dengan kemampuan digital. Dalam memenuhi kebutuhan SDM tersebut, STMM melakukan kajian program studi (prodi) baru yang menghasilkan lulusan siap kerja dalam era revolusi industri 4.0. Salah satunya adalah dengan program studi software engineerin. Penelitian kajian prodi baru di bidang digital dibutuhkan oleh lembaga perguruan tinggi untuk dapat melakukan pengambilan keputusan dalam pengembangan kelembagaan. Pengembangan lembaga menjadi salah satu tanggung jawab perguruan tinggi (Beach \& Lindahl, 2017). Hasil penelitian ini dapat membantu STMM untuk mengajukan prodi baru kepada Direktorat Jenderal Perguruan Tinggi. STMM dapat berkontribusi menjawab permasalahan kurangnya talenta digital di Indonesia.

Penelitian ini sejalan dengan penelitian yang menunjukkan hasil pendidikan tinggi di Indonesia diharapkan dapat memajukan akses, mutu, dan relevansi pendidikan tinggi ini memberi manfaat konstruktif untuk pendidikan tinggi dan rakyat Indonesia untuk lebih baik (Irawan, 2018). Penelitian oleh (Wijiharjono, 2021). menunjukkan bahwa peneliti melakukan analisis menggunakan analisis SWOT atas pembukaan prodi baru di UHAMKA. Penelitian dilaksanakan guna melihat kesiapan UHAMKA terhadap pembukaan prodi baru tersebut. Penelitian oleh (Ratnaya, Adiarta, Arsa, \& Nurhayata, 2017) menunjukkan hasil berdasarkan hasil analisis SWOT Prodi Teknik Elektro layak untuk dibuka pada Fakultas Teknik dan Kejuruan UNDIKSHA dengan memperhatikan sarana dan prasarana secara matang guna proses perkuliahan yang baik. 
Kajian ini adalah analisis awal untuk menyusun pembentukan program studi baru di STMM dalam menjawab kebutuhan SDM dalam era industri 4.0. Kajian dilakukan dengan metode analisis SWOT untuk mengetahui kekuatan, kelemahan, peluang, dan ancaman institusi. Analisis ini dilakukan dengan menganalisis situasi yang ada dengan melakukan diskusi antara rekan kerja dan atasan. Tujuan penelitian ini adalah untuk mengkaji prodi baru di STMM yang dapat meningkatkan mutu SDM Indonesia. Fokus penelitian ini adalah penyusunan prodi baru di STMM, sehingga menghasilkan visi dan misi, tujuan, sasaran, profil lulusan, standar kompetensi lulusan, bahan kajian, dan materi pembelajaran prodi baru.

\section{METODE}

Penelitian ini dilakukan dengan pendekatan secara kualitatif. Penelitian dilaksanakan di STMM, Sleman, D.I. Yogyakarta. Metode pengumpulan data yang dilakukan pada penelitian ini adalah observasi, kuesioner, wawancara, dan dokumentasi. Pengumpulan data dilakukan dengan menyebarkan kuesioner kepada para guru yang mengikuti pelatihan CTA (Coding Teacher Academy) di Yogyakarta. Hasil kuesioner tersebut untuk mengetahui minat masyarakat terhadap prodi baru di STMM. Teknis analisis data pada survey dilakukan dengan analisis deskripsi persentase, yaitu hasil data kuesioner diubah dalam bentuk persentase dan dijelaskan dalam bentuk kualitatif. Kuesioner disusun menggunakan skala likert dengan nilai 4 untuk sangat setuju, 3 setuju, 2 tidak setuju, dan 1 sangat tidak setuju. Selanjutnya, dilanjutkan dengan wawancara dari pelaku industri. Wawancara dilakukan kepada para pelaku industri di bidang digital maupun perusahaan biasa. Narasumber wawancara adalah IT General Manager dari Padang Karunia Group dan Talent Partner Manager dari Mitrais. Selanjutnya, dilakukan focus group discussion dan desk research untuk menyusun visi misi, profil lulusan, capaian pembelajaran, dan bidang yang dipelajari. Setelah data terkumpul, kemudian dianalisis dengan menggunakan analisis kualitatif deskriptif.

\section{HASIL DAN PEMBAHASAN}

\section{Hasil}

\section{Analisis Pasar Menggunakan Kuesioner}

Dengan latar belakang kebutuhan kemampuan di bidang digital untuk menghadapi era revolusi industri 4.0. Analisis pasar dilakukan untuk mengetahui mengetahui pendapat masyarakat maupun industri terhadap pembukaan prodi baru di STMM di bidang transformasi digital. Pendapat masyarakat dan industri dilakukan dengan 2 metode, menyebar kuesioner kepada guru-guru SMA/SMK yang mengikuti CTA Digitalent Scholarship yang diselenggarakan di Yogyakarta dan melakukan interview kepada stakeholder industri tentang kebutuhan tenaga dalam era revolusi industri 4.0. Guru-guru SMA/SMK berperan sebagai stakeholder yang dapat memberi rekomendasi kepada pada muridnya untuk melanjutkan pendidikan di prodi baru di STMM.

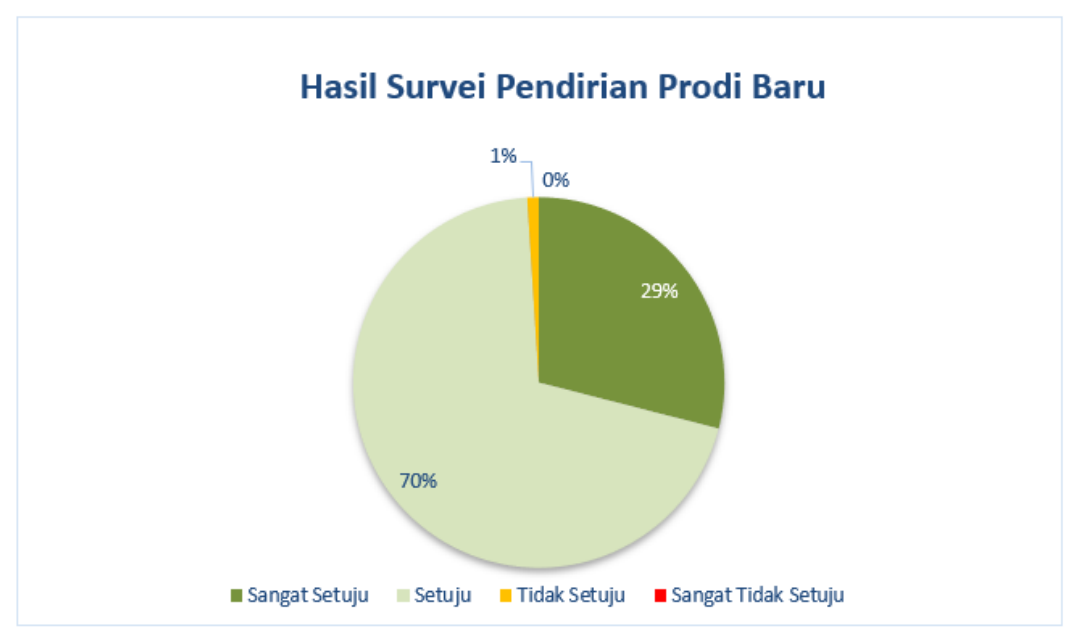

Gambar 1. Hasil Survei Pendirian Prodi Baru Software Engineering

Gambar 1 menunjukkan persentase hasil kuesioner yang telah diisi oleh responden yaitu para guru peserta CTA untuk mengetahui apakah mereka mendukung adanya program studi baru di STMM Yogyakarta. Responden yang terlibat dalam survei berjumlah 438 orang. Sebanyak $70 \%$ responden menyatakan setuju, 29\% menyatakan sangat setuju, dan $1 \%$ tidak setuju. 


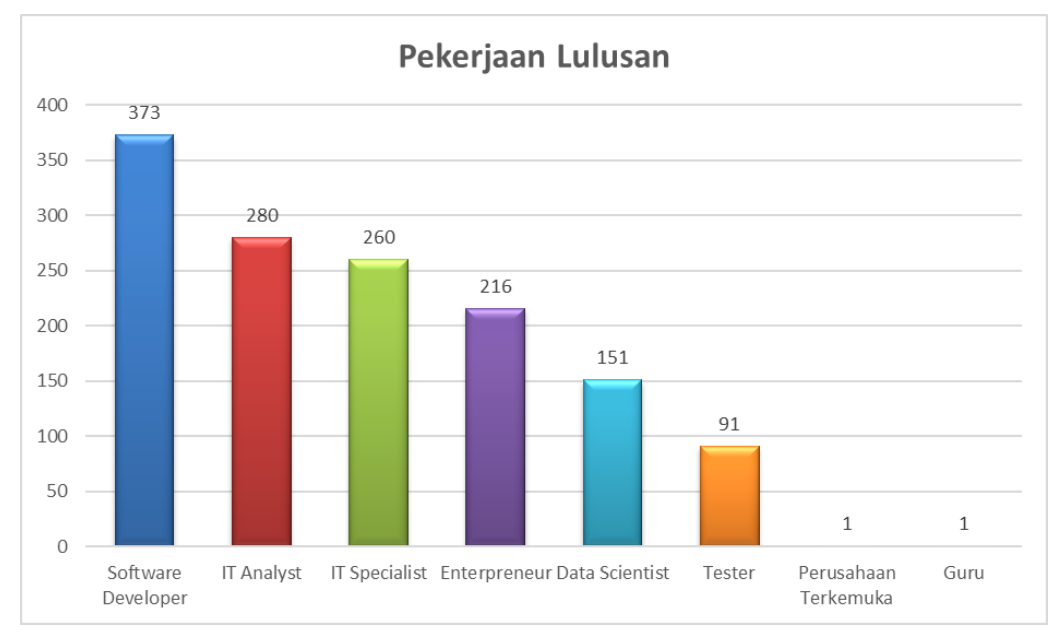

Gambar 2. Hasil Survei Pekerjaan Lulusan

Gambar 2 memuat hasil survei tentang pekerjaan lulusan yang dibutuhkan di bidang Teknologi informasi (TI). Software engineering mendapatkan peringkat pertama dengan sebanyak 373 responden yang memilih profesi ini, sebanyak 280 responden memilih IT analyst, 260 responden memilih IT specialist, 216 responden memilih entrepreneur, 151 responden memilih data scientist, 91 responden memilih tester, 1 responden memilih perusahaan terkemuka, dan 1 responden memilih guru atau pengajar sebagai profesi yang diminati di bidang TI. Dari hasil survei dapat diketahui bahwa software engineering menjadi pekerjaan lulusan yang sangat dibutuhkan oleh perusahaan.

\section{Analisis Kebutuhan Industri}

Analisis pasar juga dilakukan dengan melakukan wawancara terhadap industri, salah satunya dengan Bapak Christoferus, IT General Manager dari Padang Karunia Group. Beliau menggambarkan bahwa lulusan perguruan tinggi harus memiliki kompetensi teknis yang siap pakai, sehingga sudah dapat menerapkan ilmunya untuk pekerjaan yang dibebankan dan memiliki pengetahuan yang komprehensif tentang dunia TI. Selain kompetensi teknis, dari sisi soft skill, industri kebanyakan akan mencari orangorang yang punya passion terhadap teknologi dan memiliki pemahaman terhadap apa yang dikerjakan.

Beliau juga menyebutkan bahwa tren perkembangan industri, bisnis, dan teknologi juga sangat pesat. Dengan teknologi big data, cloud dan Artificial Intelligence yang ada sekarang ini, ke depannya akan dibutuhkan lebih banyak tenaga-tenaga ahli yang menguasai Business Intelligence, walaupun programmer, network engineering maupun data center operation itu masih akan tetap dibutuhkan. Disebutkan juga bahwa Internet of Things akan lebih banyak lagi memiliki peranan dalam industri. Saat ini sudah begitu banyak sensor-sensor mikrokontroler yang beredar, baik dari perusahaan besar maupun menengah. Beliau juga menegaskan bahwa peran CIO atau Direktorat IT kedepannya akan menjadi jabatan atau posisi yang penting dan sangat dibutuhkan dalam satu perusahaan. IT Governance juga disarankan dapat diajarkan lebih awal di masa pendidikan perguruan tinggi.

Wawancara kedua dilakukan dengan Bapak Riyan Permadi, Talent Partner Manager dari Mitrais. Beliau menyebutkan bahwa lapangan pekerjaan di Indonesia masih sangat luas pada semua lini karena semakin dibutuhkan seiring semakin banyak perusahaan yang beralih ke digital. Beliau menyebutkan juga bahwa lulusan sebaiknya langsung diarahkan ke industri. Lulusan-lulusan tersebut meliputi Programmer, IT Support, Networking, dan lain-lain. Lulusan dapat disesuaikan dengan standar kompetensi seperti SWEBOK untuk software engineering, standard CISCO untuk networking, dan untuk keterampilan lokal diarahkan ke SKKNI. Selain kompetensi secara spesifik, Bapak Riyan Permadi menyebutkan tentang penguasaan Bahasa Inggris dan soft skill yang harus dimiliki lulusan. Soft skill yang dimaksud adalah ketangguhan dalam bekerja dan keinginan belajar yang kuat.

\section{Focus Group Disscusion Kondisi STMM}

STMM adalah sebuah Perguruan Tinggi Negeri yang berada di lingkungan Kementerian Komunikasi dan Informatika RI (Kementerian Kominfo). STMM memiliki sarana dan prasarana yang memadai dalam pelaksanaan belajar mengajarnya. Kementerian Kominfo memberi dukungan penuh dalam pelaksaan perguruan tinggi di STMM. 
STMM memiliki daya tarik yang baik di masyarakat. Hal ini diketahui dari minat calon mahasiswa terhadap STMM menunjukkan peningkatan, yakni pada tahun 2014 jumlah pendaftar sebanyak 2.663 orang meningkat pada tahun 2016 hingga mencapai angka pendaftaran sebanyak 6.312 orang. Animo masyarakat terhadap STMM cukup tinggi terlihat dari angka seleksi calon mahasiswa tercatat 1:10. Dosen dan mahasiswa di STMM memiliki rasio kurang dari 1:60. Rasio ini sesuai dengan peraturan yang ditetapkan oleh Dikti. Akan tetapi, pada beberapa tahun mendatang, ada beberapa dosen yang akan menjalani masa pensiun dan belum ada perekrutan dosen baru sejauh ini. Pembukaan prodi baru ini tentu membutuhkan dosen-dosen yang kompeten di dalamnya. Kecepatan kemajuan teknologi dan persaingan antar perguruan tinggi tentu menjadi pertimbangan dalam membuat prodi baru. STMM sebaiknya tidak kalah dari kemajuan teknologi dan terus mengikuti perkembangan zaman dalam pelaksanaan belajar mengajar maupun kualitas lulusan yang dihasilkan.

\section{Program Studi Baru Software Engineering}

Hasil analisis pasar dan wawancara dengan pelaku industri menyimpulkan bahwa program studi di bidang ilmu komputer dibutuhkan pada era revolusi industri 4.0. Analisis pasar juga menyebutkan bahwa dalam menghadapi era tersebut dibutuhkan lulusan yang memiliki kompetensi teknis TI dan siap kerja di industri. Selain itu, dari hasil survei diketahui bahwa pekerjaan lulusan yang sangat dibutuhkan industri adalah pada software engineering. Oleh karena itu, STMM mengambil peluang untuk membuka prodi baru software engineering atau rekayasa perangkat lunak(RPL). Dalam penyusunan visi dan misi prodi baru, dilakukan diskusi dengan para dosen di STMM. Kata kunci dalam menentukan visi dan misi prodi adalah tujuan prodi ini dan juga kaitannya dengan tri dharma perguruan tinggi. Selanjutnya, dalam penyusunan kurikulum yang berpedoman dengan capaian lulusan dan capaian pembelajaran salah satu caranya adalah melakukan diskusi dengan stakeholder industri pada bidang ilmu RPL. Kata kunci yang diambil dalam penyusunan kurikulum adalah spesifik keterampilan teknis dan kurikulum mengacu pada Standar Kompetensi Kerja Nasional Indonesia (SKKNI). Dalam mencapai SKKNI, penyusunan kurikulum dilakukan dengan berbasis KKNI. Oleh karena itu, penyusunan kurikulum prodi ini berbasis KKNI.

Dilanjutkan dengan capaian pembelajaran berdasarkan KKNI level 6 dan SNPT yang terdiri dari : (1) Sikap dan Tata Nilai, (2) Keterampilan Kerja Umum, (3) Keterampilan Kerja Khusus, (4) Penguasaan Pengetahuan. Adapun profil lulusan dan capaian pembelajaran dirumuskan pada Tabel 1.

Tabel 1. Profil Lulusan Program Studi Software Engineering

\begin{tabular}{|c|c|c|}
\hline No & Profil Lulusan & Capaian \\
\hline 1. & System Analyst & $\begin{array}{l}\text { Mampu menganalisis dan menspesifikasikan kebutuhan perangkat lunak } \\
\text { sesuai dengan tujuan perusahaan. }\end{array}$ \\
\hline 2. & Software Developer & $\begin{array}{l}\text { Mampu mengembangkan perangkat lunak dengan menerapkan metodologi } \\
\text { pengembangan perangkat lunak yang sesuai dengan perkembangan terkini } \\
\text { agar menghasilkan perangkat lunak yang sesuai dengan kebutuhan } \\
\text { pengguna. }\end{array}$ \\
\hline 3. & Software Tester & $\begin{array}{l}\text { Mampu melakukan pengujian perangkat lunak menggunakan metode black } \\
\text { box dan atau white box sesuai kebutuhan. }\end{array}$ \\
\hline 4. & Technop & $\begin{array}{l}\text { Mampu memiliki semangat kemandirian kejuangan dan kewirausahaan, } \\
\text { serta mampu menunjukkan sikap bertanggung jawab, jujur, dan disiplin } \\
\text { atas pekerjaan bidang keahliannya secara mandiri. }\end{array}$ \\
\hline 5. & Data Scientist & $\begin{array}{l}\text { Mampu mengolah data besar menjadi suatu pengetahuan yang dibutuhkan } \\
\text { bagi perusahaan, penelitian, atau keperluan yang lain }\end{array}$ \\
\hline 6. & Manager Proyek & Mampu mengelola proyek TI dengan efektif dan efisien. \\
\hline
\end{tabular}

\section{Rancangan Kurikulum Software Engineering}

Penyusunan kurikulum memiliki tingkat kedalaman dan keluasan materi yang mengacu pada Capaian Pembelajaran Lulusan. Hal tersebut tercantum dalam SN-Dikti pasal 9, ayat (2) untuk jenjang program studi S1 adalah menguasai konsep teoritis bidang pengetahuan dan keterampilan tertentu secara umum dan konsep teoritis bagian khusus dalam bidang pengetahuan dan keterampilan tersebut secara mendalam. Rancangan kurikulum ini dapat menghasilkan SDM yang siap kerja(Suteja, 2017).

Perumusan bahan pembelajaran prodi software engineering mengacu pada SWEBOK V.3, Computing Curricula dan Software Engineering. Bahan kajian prodi baru tersebut selanjutnya dipetakan menjadi mata kuliah-mata kuliah yang sesuai. Hal tersebut tergambar pada Tabel 2. 
Tabel 2. Bahan Kajian dan Mata Kuliah

\begin{tabular}{|c|c|c|c|}
\hline No & $\begin{array}{c}\text { Bidang Ilmu } \\
\text { yang Dipelajari }\end{array}$ & Bahan Kajian & Mata Kuliah \\
\hline 2. & $\begin{array}{l}\text { Software } \\
\text { requirements }\end{array}$ & $\begin{array}{ll}\text { - } & \text { Kepribadian } \\
\text { - } & \text { Humaniora } \\
\text { - } & \text { Agama } \\
\text { - } & \text { Nasionalisme } \\
\text { - } & \text { Ktika Profesi } \\
\text { - } & \text { Bahasa } \\
\text { - } & \text { Kebutuhan Perangkat Lunak } \\
\text { - } & \text { Pundamental } \\
\text { - } & \text { Elisitasi Kebutuhan } \\
\text { - } & \text { Analisis Kebutuhan } \\
\text { - } & \text { Spesifikasi Kebutuhan } \\
\text { - } & \text { Palidasi Kebutuhan } \\
\text { - } & \text { Alat Kebutuhan Perangkat } \\
& \text { Lunak }\end{array}$ & $\begin{array}{ll}\text { - } & \text { Pendidikan Agama } \\
\text { - } & \text { Pendidikan Pancasila } \\
\text { - } & \text { Bahasa Indonesia } \\
\text { - } & \text { Bahasa Inggris Dasar } \\
\text { - } & \text { Bahasa Inggris Scientific } \\
\text { - } & \text { Bahasa Inggris Profesional } \\
\text { - } & \text { Kewirausahaan } \\
\text { - } & \text { Etika profesi } \\
\text { - } & \text { Pemrograman Komputer } \\
\text { - } & \text { Analisis dan Desain perangkat } \\
& \text { lunak }\end{array}$ \\
\hline 3. & Software design & 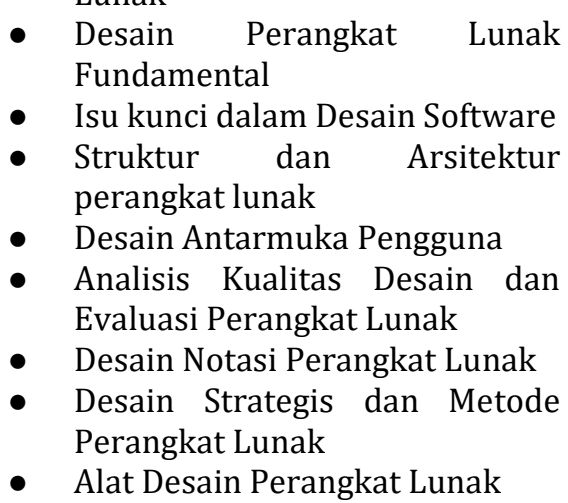 & $\begin{array}{ll}\text { - Analisis dan Desain Perangkat } \\
\text { - Lunak } \\
\text { - Pemrograman Komputer } \\
\text { Interaksi Manusia dan } \\
\text { Komputer }\end{array}$ \\
\hline 4. & $\begin{array}{c}\text { Software } \\
\text { construction }\end{array}$ & $\begin{array}{ll}\text { - } & \text { Konstruksi perangkat lunak } \\
\text { - } & \text { Mundamentals } \\
\text { - } & \text { Pengelola Konstruksi } \\
\text { - } & \text { Teknologi Konstruksi } \\
\text { - } & \text { Alat Konstruksi Perangkat } \\
& \text { Lunak }\end{array}$ & $\begin{array}{l}\text { - } \quad \text { Konstruksi Perangkat Lunak } \\
\text { - Pengantar Teknologi Informasi } \\
\text { dan Komunikasi }\end{array}$ \\
\hline 5. & Software testing & $\begin{array}{ll}\text { - } & \text { Pengujian Perangkat Lunak } \\
& \text { Fundamental } \\
\text { - } & \text { Level Pengujian } \\
\text { - } & \text { Teknik Pengujian } \\
\text { - } & \text { Test-Related Measures } \\
\text { - } & \text { Proses Pengujian } \\
\text { - } & \text { Alat Pengujian Perangkat Lunak }\end{array}$ & $\begin{array}{l}\text { - Pengujian Kualitas Perangkat } \\
\text { Lunak } 1\end{array}$ \\
\hline 6. & $\begin{array}{l}\text { Software } \\
\text { maintenance }\end{array}$ & $\begin{array}{l}\text { - Pemeliharaan Perangkat Lunak } \\
\text { - } \quad \text { Isundamental Kunci dalam Pemeliharaan } \\
\text { - Perangkat Lunak } \\
\text { - Proses Pemeliharaan } \\
\text { - Teknik untuk Pemeliharaan } \\
\text { - Software maintenance tools }\end{array}$ & - $\quad$ Sistem informasi \\
\hline 7. & $\begin{array}{l}\text { Software } \\
\text { engineering } \\
\text { management }\end{array}$ & $\begin{array}{l}\text { - Inisiasi dan Ruang Lingkup } \\
\text { Definisi } \\
\text { - Perencanaan Proyek Perangkat } \\
\text { - Lunak } \\
\text { Pengesahan Proyek Perangkat }\end{array}$ & $\begin{array}{ll}\text { - } & \text { Manajemen proyek Perangkat } \\
& \text { Lunak } \\
\text { - } & \text { Proyek } 1 \\
\text { - } & \text { Proyek } 2 \\
\text { - } & \text { Proyek } 3\end{array}$ \\
\hline
\end{tabular}




\begin{tabular}{|c|c|c|c|}
\hline No & $\begin{array}{c}\text { Bidang Ilmu } \\
\text { yang Dipelajari }\end{array}$ & Bahan Kajian & Mata Kuliah \\
\hline 8. & $\begin{array}{c}\text { Software } \\
\text { development } \\
\text { process }\end{array}$ & 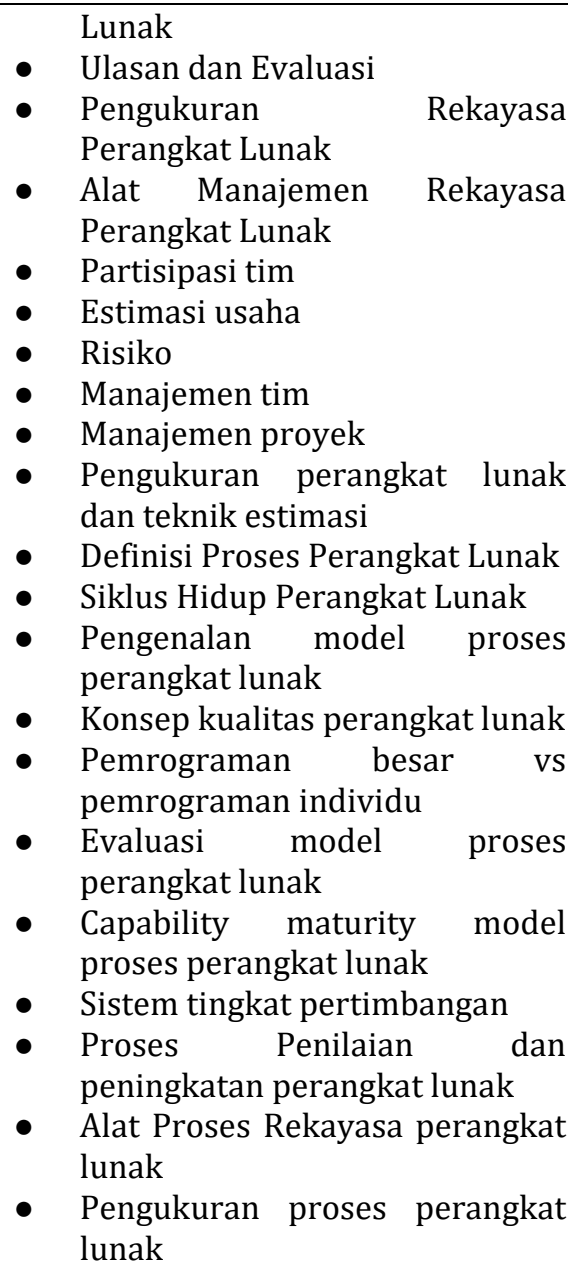 & $\begin{array}{ll}\text { - } & \text { Pengembangan perangkat } \\
& \text { lunak berorientasi objek } \\
\text { - } & \text { Pemrograman } \\
& \text { Objek } 1 \\
\text { - } & \text { Pemrograman } \\
& \text { Objek } 2 \\
\text { - } & \text { Pemrograman web } 1 \\
\text { - } & \text { Pemrograman web } 2 \\
\text { - } & \text { Artificial Intelligence }\end{array}$ \\
\hline 9. & Software quality & $\begin{array}{ll}\text { - } & \text { Kualitas Perangkat Lunak } \\
\text { - } & \text { Pundamental } \\
& \text { Proses Manajemen Mutu } \\
\text { - } & \text { Pertimbangan teknis } \\
\text { - } & \text { Alat Kualitas perangkat lunak } \\
\text { - } & \text { Teknik Pemecahan Masalah } \\
\text { - } & \text { Abstraksi } \\
\text { - } & \text { Dasar-dasar pemrograman }\end{array}$ & $\begin{array}{l}\text { - Pengujian Kualitas Perangkat } \\
\text { Lunak } \\
\text { - Pemrograman komputer }\end{array}$ \\
\hline 10. & $\begin{array}{l}\text { Computing } \\
\text { foundations }\end{array}$ & $\begin{array}{ll}\text { - } & \text { Dasar-dasar } \\
\text { - } & \text { Pemrograman } \\
\text { - } & \text { Struktur data dan representasi } \\
\text { - } & \text { Algoritma dan kompleksitas } \\
\text { - } & \text { Konsep dasar dari sistem } \\
\text { - } & \text { Organisasi komputer } \\
\text { - } & \text { Dasar Sistem Operasi } \\
\text { - } & \text { Dasar compiler } \\
\text { - } & \text { Dasar-dasar database dan } \\
\text { - } & \text { Danajemen data } \\
\text { - } & \text { Komunikasi dasar } \\
\text { - } & \text { Basic User Human Factors } \\
\text { - } & \text { Basic Developer Human Factors }\end{array}$ & $\begin{array}{ll}\text { - } & \text { Struktur Data \& Analisis } \\
& \text { Algoritma } \\
\text { - } & \text { Pengantar Algoritma } \\
\text { - } & \text { Pengantar sistem komputer } \\
\text { - } & \text { Arsitektur computer } \\
\text { - } & \text { Sistem Operasi } \\
\text { - } & \text { Sistem basis data } \\
\text { - } & \text { Sistem terdistribusi } \\
\text { - } & \text { Jaringan komputer } \\
\text { - } & \text { Keamanan system }\end{array}$ \\
\hline
\end{tabular}




\begin{tabular}{|c|c|c|c|}
\hline No & $\begin{array}{c}\text { Bidang Ilmu } \\
\text { yang Dipelajari }\end{array}$ & Bahan Kajian & Mata Kuliah \\
\hline 11. & $\begin{array}{l}\text { Mathematical } \\
\text { foundations }\end{array}$ & $\begin{array}{ll}\text { - } & \text { Pengembangan } \\
& \text { Pemeliharaan } \\
& \text { perangkat lunak } \\
\text { - } & \text { Set, Relasi, Fungsi } \\
\text { - } & \text { Logika Dasar } \\
\text { - } & \text { Teknik Pembuktian } \\
\text { - } & \text { Dasar-dasar dari Counting } \\
\text { - } & \text { Grafik } \\
\text { - } & \text { Metode Empiris dan Teknik } \\
\text { - } & \text { Eksperimental } \\
\text { Analisis Statistik }\end{array}$ & $\begin{array}{ll}\text { - } & \text { Kalkulus } 1 \\
\text { - } & \text { Kalkulus } 2 \\
\text { - } & \text { Matematika Diskrit } 1 \\
\text { - } & \text { Matematika Diskrit } 2 \\
\text { - } & \text { Aljabar Linear } \\
\text { - } & \text { Statistika } \\
\text { - } & \text { Grafika Komputer } \\
\text { - } & \text { Pemodelan Perangkat Lunak }\end{array}$ \\
\hline 12. & $\begin{array}{l}\text { Engineering } \\
\text { foundations }\end{array}$ & $\begin{array}{ll}\text { - } & \text { Pengukuran } \\
\text { - } & \text { Desain Teknik } \\
\text { - } & \text { Pemodelan, Prototyping, dan } \\
& \text { simulasi } \\
\text { - } & \text { Standards } \\
\text { - } & \text { Analisis Permasalahan }\end{array}$ & \\
\hline 13. & $\begin{array}{l}\text { Sistem Informasi } \\
\text { Korporat }\end{array}$ & $\begin{array}{l}\text { - } \quad \text { Tata kelola TI perusahaan } \\
\text { - } \quad \text { Manajemen resiko perusahaan } \\
\text { - } \quad \text { Audit teknologi informasi } \\
\text { - } \quad \text { Big data }\end{array}$ & $\begin{array}{ll}\text { - } & \text { Manajemen resiko } \\
\text { - } & \text { Tata Kelola TI } \\
\text { - } & \text { Audit Sistem Informasi } \\
\text { - } & \text { Pembelajaran mesin }\end{array}$ \\
\hline 14. & $\begin{array}{l}\text { Business } \\
\text { Intelligent }\end{array}$ & $\begin{array}{l}\text { - } \quad \text { Data mining } \\
\text { - } \quad \text { Machine learning }\end{array}$ & $\begin{array}{l}\text { - Data Mining,Warehouse, Text } \\
\text { dan Web Mining } \\
\text { - Analisis Big Data }\end{array}$ \\
\hline 15. & $\begin{array}{l}\text { Ubiquitous } \\
\text { Computing }\end{array}$ & $\begin{array}{ll}\text { - } & \text { Pengetahuan tentang cloud } \\
\text { - } & \text { Mixed Reality } \\
\text { - } & \text { Internet of Things } \\
\text { - } \quad \text { Blockchain }\end{array}$ & $\begin{array}{ll}\text { - } & \text { Komputasi Awan } \\
\text { - } & \text { Mixed Reality } \\
\text { - } & \text { Internet of Things } \\
\text { - } & \text { Blockchain } \\
\end{array}$ \\
\hline
\end{tabular}

Dilanjutkan dengan pemetaan bahan kajian dan mata kuliah menjadi pohon kurikulum prodi seperti tergambar pada Gambar 3.

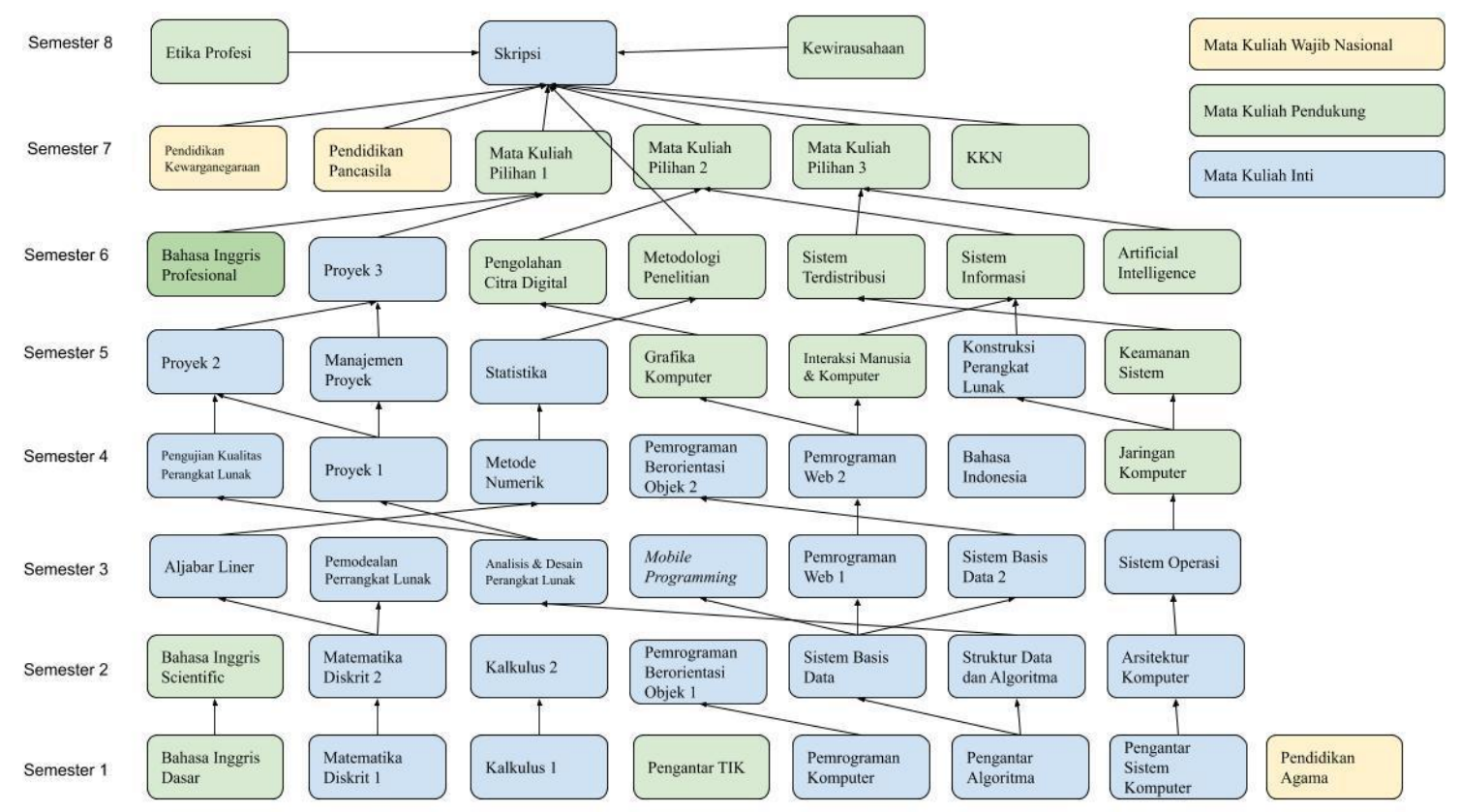

Gambar 3. Pohon Kurikulum Software Engineering

Pada pohon kurikulum Software Engineering terdapat mata kuliah wajib nasional, mata kuliah pendukung, dan mata kuliah inti. Terdapat anak panah yang menunjukkan hubungan dan alur mata 
kuliah. Alur ini dapat membantu mahasiswa dalam memetakan topik skripsi yang akan diambil. Total SKS yang harus diambil mahasiswa program sarjana (S1) antara 144 sampai dengan 160 SKS.

\section{Analisis SWOT}

Analisis internal STMM dilakukan dengan analisis Strength, Weaknesses, Opportunities, dan Threats (SWOT) untuk mengetahui kesiapan STMM dalam membentuk prodi baru. Hasil analisis SWOT antara lain adalah sebagai berikut.

\section{Strength}

STMM memiliki potensi untuk mengembangkan prodi baru di bidang digital. STMM berada pada lokasi yang strategis. Sebagai institusi di bawah pemerintah, STMM memiliki sarana dan prasarana yang mampu mendukung pembukaan prodi baru. Selain itu juga, prodi baru di bidang digital ini selaras dengan peta jalan Kementerian Kominfo yang mendukung percepatan transformasi digital (Fauzia, Virantika, \& Firmansyah, 2021). Hal ini termasuk dalam aspek Strength dalam pendekatan analisis SWOT.

\section{Weakness}

Pembukaan prodi baru di STMM tentu membutuhkan tenaga dosen yang kompeten dalam kegiatan belajar mengajarnya, tetapi beberapa dosen akan memasuki pensiun dalam waktu beberapa tahun ke depan dan belum ada perekrutan dosen baru dalam waktu dekat ini. Kelemahan ini termasuk dalam aspek Weakness dalam pendekatan analisis SWOT.

\section{Opportunities}

Hasil analisis pasar menggunakan kuesioner, lebih dari 70\% menyatakan setuju untuk membuka prodi baru. Hal ini masuk dalam aspek opportunity dalam pendekatan analisis SWOT. Selain hasil survey, pada FGD juga menghasilkan beberapa kesepakatan, antara lain : mengembangkan lembaga STMM di bidang digital. Hal ini juga termasuk dalam aspek Opportunity. Analisis kebutuhan industri juga memperlihatkan peluang kerja yang besar bagi lulusan perguruan tinggi yang memiliki keterampilan digital. Disebutkan bahwa peluang kerja di bidang digital masih terbuka lebar. Temuan ini termasuk dalam masuk Opportunity dalam pendekatan analisis SWOT. Analisis SWOT juga menyebutkan adanya peluang di era revolusi industri dan dukungan penuh dari Kementerian Kominfo.

\section{Threats}

STMM sebagai perguruan tinggi bertanggung jawab dalam berkontribusi pemenuhan lulusan dengan SDM yang berkualitas baik dalam soft skill dan hard skill. Oleh karena itu STMM harus bisa mengikuti perkembangan teknologi yang pekembangannya sangat cepat. STMM juga mampu bersaing dengan perguruan lain sebagai perguruan tinggi yang unggul. Lulusan STMM juga harus unggul dalam bersaing dengan perguruan tinggi lain. Hal ini termasuk dalam Threats dalam pendekatan analisis SWOT. Pemetaan pembahasan SWOT terlihat pada Gambar 4.

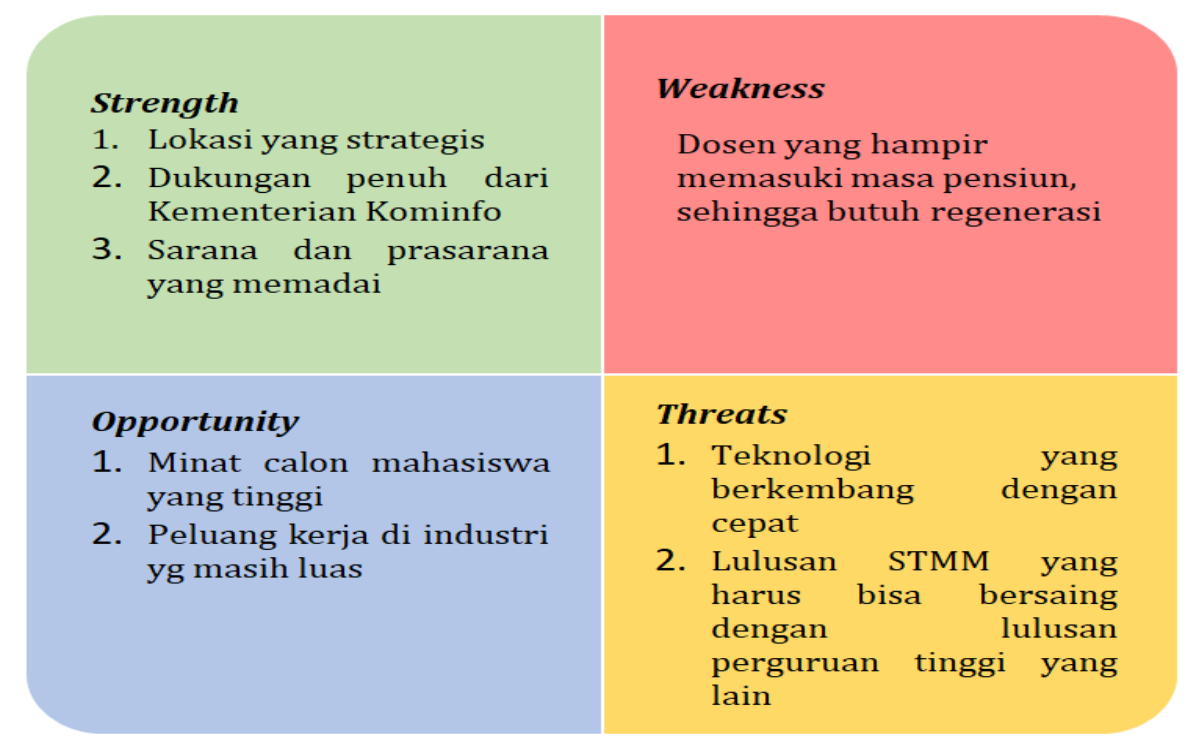

Gambar 4. Pemetaan SWOT STMM 


\section{Pembahasan}

Hasil penyusunan kurikulum dilakukan berdasarkan kajian pustaka antara lain : Peraturan Presiden No. 8 tahun 2012 tentang Kerangka Kualifikasi Nasional Indonesia (KKNI) mengatur tentang jenjang, penyetaraan, dan penerapan kualifikasi sumber daya manusia Indonesia. Prodi baru pada strata 1 pada jenjang 6 pada KKNI (Junaidi, 2020). Standart nasional yang digunakan untuk menyusun kurikulum prodi baru adalah KKNI dan SNPT (Direja, 2017; Suwadi, 2016). Selain standart nasional, penyusunan ini juga mengadopsi standart Internasional Institute of Electrical and Electronics Engineers (IEEE). IEEE mendefinisikan software engineering sebagai penerapan pendekatan yang sistematis, disiplin, dan terukur untuk pengembangan, pengoperasian, dan pemeliharaan perangkat lunak. Sebagian besar aktivitas yang terlibat dalam pengembangan dan evolusi perangkat lunak cenderung menggunakan proses berbasis tim yang mewujudkan beberapa bentuk elemen desain, mulai dari pilihan awal arsitektur tingkat tinggi hingga pilihan strategi pengujian dan evaluasi (Verhoef et al., 2021).

Tidak terbatas KKNI dan IEEE, pengembangan prodi baru ini juga mengikuti era transformasi digital. Transformasi digital adalah proses perusahaan menyatukan banyak teknologi digital baru ditingkatkan dengan konektivitas di mana-mana. Transformasi digital memiliki tujuan dalam mencapai kinerja yang unggul dan keunggulan kompetitif yang berkelanjutan dengan mengubah beberapa dimensi bisnis (Cokki, Soelaiman, \& Puspitowati, 2019; Yunus et al., 2021). Ruang lingkup meliputi model bisnis, pengalaman pelanggan, kegiatan operasional, dan secara simultan berdampak pada orang serta seluruh jaringan sistem nilai (Ismail, Khater, \& Zaki, 2017). Dalam mewujudkan transformasi digital diperlukan cross sectional organizational change, yaitu perubahan pada semua unit dalam penggunaan teknologi digital untuk mencapai tujuan institusi. Perubahan harus dilakukan pada setiap unit yang terlibat agar hambatan yang dihadapi semakin kecil (Maksum \& Fitria, 2021; Shavab, 2020).

Dalam menghadapi transformasi digital, pengajar di era 4.0 harus memiliki kecakapan yaitu: (1) kompetensi mendidik berbasis internet of thing; (2) kompetensi pemanfaat teknologi untuk sikap kewirausahaan; (3) kompetensi dalam globalisasi; (4) kompetensi dalam strategi di masa mendatang; (5) kompetensi sebagai konselor. Dilakukan peningkatan fasilitas jaringan siber sebagai bagian integrasi dengan jaringan teknologi informatika di lembaga pendidikan akan menciptakan berbagai kemudahan, baik dalam administrasi akademik, non akademik, dan proses belajar mengajar, yang bermuara kepada peningkatan kualitas SDM output dari sebuah lembaga pendidikan. Bila hal ini dapat terwujud secara merata di seluruh penjuru tanah air, maka pendidik di Indonesia mampu memasuki pendidikan era revolusi Industri 4.0 (Putri, Herdiana, Suharya, \& Munawar, 2021; Suci, Indrawan, Wijoyo, \& Kurniawan, 2020). Prodi Software Engineering berdasarkan transformasi digital sesuai dengan kondisi era industri 4.0. Transformasi digital membuka peluang baru di bidang teknologi informasi. Kurikulum prodi baru ini disusun dengan memasukkan bidang-bidang transformasi digital seperti cloud computing, big data, AI dan machine learning. Hal tersebut didukung penelitian yang dilakukan oleh Smetanina dan kawan-kawan, bahwa transformasi digital membuka peluang pada bidang cloud computing, Internet of Things-IoT, big data, blockchain, artificial intelligence-AI, dan machine learning-ML (Smetanina, Yefremova, \& Lazutkina, 2020).

Lulusan prodi ini diharapkan cakap digital dan mampu memberi kontribusi yang efektif dalam industri. Disebutkan juga bahwa transformasi digital dalam industri mampu membantu industri untuk memberikan solusi-solusi dalam perusahaan dan mampu bersaing dalam era digital (Gebhart, Giessler, \& Abeck, 2016). Susunan kurikulum dalam prodi baru ini memberikan keterampilan-keterampilan digital yang dibutuhkan dalam industri, salah satunya mata kuliahnya adalah programming. Dikuatkan dengan penelitian yang menyebutkan pelatihan dan pelajaran terkait dengan teknologi informasi dan komunikasi dapat meningkatkan keterampilan digital yang dibutuhkan untuk menjadi professional IT (Privalov, Bogatyreva, \& Romanov, 2019). Penelitian ini membahas juga bahwa pendidikan IT yang mendukung kebutuhan industri dapat menjawab kebutuhan SDM digital di industri.

Perkembangan teknologi informasi dan komunikasi yang pesat dan era industry 4.0 memberikan tantangan kepada perguruan tinggi untuk terus berkembang menghasilkan lulusan-lulusan yang mampu bersaing dalam era ini (Chorosova, Aetdinova, Solomonova, \& Gerasimova, 2020) . Keterampilanketerampilan digital dibutuhkan untuk menjawab tantangan tersebut. Oleh karena itu, diharapkan prodi Software Engineering memiliki kurikulum yang sesuai dengan kebutuhan industri dapat menjawab tantangan tersebut.

\section{SIMPULAN}

Berdasarkan hasil kajian studi literatur, analisis survei, dan analisis SWOT dapat disimpulkan bahwa pendirian program studi Software Engineering mendapat antusias dan respon yang baik dari berbagai stakeholder. Hasil penelitian menunjukkan bahwa Software Engineer menjadi profesi yang sangat 
ibutuhkan perusahaan di era industri 4.0 pada program studi Software Engineering. Program studi Software Engineering diharapkan mampu mencetak SDM yang kompeten dan berkontribusi untuk pembangunan Indonesia maupun global agar potensi digital Indonesia tidak tertinggal. Diharapkan pembentukan program studi Software Engineering dapat mendukung transformasi digital.

\section{DAFTAR RUJUKAN}

Astini, Sari, N. K. (2020). Pemanfaatan Teknologi Informasi dalam Pembelajaran Tingkat Sekolah Dasar pada Masa Pandemi Covid-19. Jurnal Lembaga Penjaminan Mutu STKIP Agama Hindu Amlapura, 11(2), 13-25. https://e-journal.stkipamlapura.ac.id/index.php/jurnallampuhyang/article/view/194.

Balyer, A., \& Oz, O. (2018). Academicians' Views on Digital Transformation in Education. International Online Journal of Education and Teaching (IOJET), 5(4), 809-830.

Beach, R. H., \& Lindahl, R. A. (2017). Instituting a New Degree Program: A Case Study of University Planning. Planning for Higher Education Journal, 45(4), 32-44.

C.Verhoef, P., Broekhuizen, T., Bart, Y., Bhattacharya, A., Dong, J. Q., Fabian, N., \& Haenlein, M. (2021). Digital Transformation: A Multidisciplinary Reflection and Research Agenda. Journal of Business Research, 122, 889-901. https://doi.org/10.1016/j.jbusres.2019.09.022.

CC2020 Task Force. (2020). Computing Curricula 2020. Computing Curricula 2020. https://doi.org/10.1145/3467967.

Chorosova, O. M., Aetdinova, R. R., Solomonova, G. S., \& Gerasimova, R. E. (2020). Spring 2020: toward a Digital Transformation of Education. In VI International Forum on Teacher Education (Vol. 1, pp. 381-393). https://doi.org/10.3897/ap.2.e0381.

Cokki, Soelaiman, L., \& Puspitowati, I. (2019). Transformasi Digital Merek-Merek Indonesia dalam Bentuk Penempatan Produk pada Web Series di Situs Web Youtube. D EReMa Jurnal Manajemen, 14(1), 155-170. https://doi.org/10.19166/derema.v14i1.1305.

Danuri, M. (2019). Perkembangan dan Transformasi Teknologi Digital. Infokam, XV(II).

Das, K., Gryseels, M., Sudhir, P., \& Tan, K. T. (2016). Unlocking Indonesia's Digital Opportunity. McKinsey \& Company, (October).

Direja, A. C. (2017). Studi Implementasi Kurikulum Berbasis KKNI pada Program Studi S1 Ilmu Komunikasi Universitas Informatika dan Bisnis Indonesia. Edutech, 16(2). https://doi.org/10.17509/e.v16i2.7756.

Everett, Gerard D; McLeod, R. J. (2007). Software Testing Testing Accrosst the Entire Software Development Life Cycle. New Jersey: IEEE Press.

Fauzia, F., Virantika, A., \& Firmansyah, G. (2021). Langkah-langkah Strategis Pemenuhan Kebutuhan SDM Talenta Digital di Lingkungan Pemerintahan Indonesia, 39-46. https://prosiding.konik.id/index.php/konik/article/view/15.

Gebhart, M., Giessler, P., \& Abeck, S. (2016). Challenges of the Digital Transformation in Software Engineering. The Eleventh International Conference on Software Engineering Advances Challenges, (c), 136-141.

Irawan, D. E. (2018). Kajian Pendidikan Tinggi IDRI untuk DPR RI dan Ristek Dikti 2018. https://doi.org/10.31227/OSF.IO/NRB9K.

Ismail, M. H., Khater, M., \& Zaki, M. (2017). Digital Business Transformation and Strategy: What Do We Know So Far? Manufacturer Article, (January), 36. https://doi.org/10.13140/RG.2.2.36492.62086.

Junaidi, A. (2020). Panduan Penyusunan Kurikulum Pendidikan Tinggi. (S. S. Kusumawardani, Ed.). Direktorat Jenderal Pendidikan Tinggi Kementerian Pendidikan dan Kebudayaan.

Latip, A. (2020). Peran Literasi Teknologi Informasi dan Komunikasi pada Pembelajaran Jarak Jauh di Masa Pandemi Covid-19. EduTeach : Jurnal Edukasi Dan Teknologi Pembelajaran, 1(2), 108 - 116. https://ejurnal.umri.ac.id/index.php/eduteach/article/view/1956.

Maksum, A., \& Fitria, H. (2021). Transformasi dan Digitalisasi Pendidikan Dimasa Pandemi. In Prosiding Seminar Nasional Pendidikan Program Pascasarjana Universitas PGRI Palembang 15-16 Januari $2021 \quad$ (pp. 121-127). https://jurnal.univpgripalembang.ac.id/index.php/Prosidingpps/article/download/5498/4827.

Masykur, R., Rosidin, U., \& Iqbal, A. M. (2018). Implementasi Kurikulum KKNI pada Program Studi Matematika Universitas Islam Negeri Raden Intan Lampung. NUMERICAL: Jurnal Matematika Dan Pendidikan Matematika. https://doi.org/10.25217/numerical.v2i1.205.

Mawangi, G. T. (n.d.). Kemkominfo Akan Ubah STMM Yogyakarta Jadi Institut Digital Nasional.

Nugrahadi, E. W., Maipita, I., Ane, L., \& Putra, P. D. (2018). Analisis Implementasi Kurikulum Berbasis KKNI di Fakultas Ekonomi Unimed. Niagawan, 7(1). https://doi.org/10.24114/niaga.v7i1.9349. 
OECD. (2020). Digital Transformation in the Age of COVID-19: Building Resilience and Bridging Divides. Digital Economy Outlook 2020 Supplement, 215(October), 438-443. https://www.oecd.org/digital/digital-economy-outlook-covid.pdf.

Pertiwi, W. K. (2020). Jokowi: Indonesia Butuh Lebih Banyak Software Engineer dan Kreator Konten.

Privalov, A. N., Bogatyreva, Y. I., \& Romanov, V. A. (2019). Engineering Centre as Innovative Component of Professional Training of Future IT Specialists. Obrazovanie $i$ Nauka, 21(7), 90-112. https://doi.org/10.17853/1994-5639-2019-7-90-112.

Putri, N. I., Herdiana, Y., Suharya, Y., \& Munawar, Z. (2021). Kajian Empiris pada Transformasi Bisnis Digital. ATRABIS: Jurnal Administrasi Bisnis, 7(1), 1-15. Retrieved from https://jurnal.plb.ac.id/index.php/atrabis/article/view/600.

Raibowo, S., \& Nopiyanto, Y. E. (2020). Evaluasi Pembelajaran Pendidikan Jasmani Olahraga \& Kesehatan pada SMP Negeri se-Kabupaten Mukomuko melalui Pendekatan Model Context, Input, Process \& Product ( CIPP ). Jurnal Pendidikan Kesehatan Rekreasi, 6(2), 146-165. https://doi.org/10.5281/zenodo.3881891.

Ratnaya, I. G., Adiarta, A., Arsa, I. P. S., \& Nurhayata, I. G. (2017). Studi Kelayakan Pembukaan Prodi S1 Teknik Elektro. Seminar Nasional Vokasi Dan Teknologi (SEMNASVOKTEK), 272-275. http://ftk.undiksha.ac.id/semnasvoktek2017/assets/Prosiding_SEMNASVOKTEK_2017.pdf.

Risdianto, E. (2019). Analisis Pendidikan Indonesia di Era Revolusi Industri 4.0. Bengkulu. Universitas Bengkulu.

Sasongko, Y. A. T. 2021. (n.d.). Menkominfo: Indonesia Butuh 600.000 Talenta Digital untuk Atasi Digital Talent Gap.

Shavab, O. A. K. (2020). Literasi Digital melalui Pemanfaatan Media Pembelajaran Edmodo pada Pembelajaran Sejarah. Sejarah Dan Budaya, 14(2), 142-152. https://doi.org/10.17977/um020v14i22020p142-152.

Smetanina, M. D., Yefremova, E. P., \& Lazutkina, E. V. (2020). Digital Transformation of Higher Education. Siberian Journal of Anthropology, 4(3), 178-184. https://doi.org/10.31804/2542-1816-2020-4-3178-184.

Society, I. C. (n.d.). Guide to the Software Engineering Body of Knowledge Version 3.0 (SWEBOK Guide V3.0).

Suci, I. G. S., Indrawan, I., Wijoyo, H., \& Kurniawan, F. (2020). Transformasi Digital Dan Gaya Belajar (Vol. 1). http://eprints.binadarma.ac.id/4348/.

Suteja, J. (2017). Model-Model Pembelajaran dalam Kurikulum Berbasis Kompetensi KKNI di Perguruan Tinggi (Perubahan dari Teacher Centered Learning ke Arah Student Centered Learning). Jurnal Edueksos, VI(1). https://doi.org/10.24235/edueksos.v6i1.1412.

Suwadi. (2016). Pengembangan Kurikulum Pendidikan Agama Islam pada Pendidikan Tinggi Mengacu KKNI-SNPT Berparadigma Interkoneksi di Program Studi PAI FITK UIN Sunan Kalijaga Yogyakarta. Jurnal Pendidikan Agama Islam, 2. http://ejournal.uinsuka.ac.id/tarbiyah/index.php/jpai/article/view/1414.

Tanjung, A. (2020). Pengembangan Kurikulum KKNI pada Matakuliah Konversi Energi Listrik. JURNAL TEKNIK, 14(1). https://doi.org/10.31849/teknik.v14i1.4206.

Tegeh, I. M., Simamora, A. H., \& Dwipayana, K. (2019). Pengembangan Media Video Pembelajaran dengan Model Pengembangan 4D pada Mata Pelajaran Agama Hindu. Julnar Mimbar Ilmu. http://dx.doi.org/10.23887/mi.v24i2.21262.

Waseso, H. P., \& Hidayat, M. S. (2017). Penerapan Kurikulum Berbasis KKNI pada Prodi PGMI Unsiq Jawa Tengah. JIP: Jurnal Ilmiah PGMI, 3(1). https://doi.org/10.19109/jip.v3i1.1376.

Widnyani, N. M., \& Ni Luh Putu Surya Astitiani, B. C. L. P. (2021). Penerapan Transformasi Digital pada UKM selama Pandemi Covid-19 di Kota Denpasar. Jurnal Ilmiah Manajemen Dan Bisnis, 6(1), 7987. Retrieved from http://journal.undiknas.ac.id/index.php/manajemen.

Wijiharjono, N. (2021). Business Analytics untuk Perguruan Tinggi: Studi Kasus atas Pembukaan Program Studi Baru di UHAMKA. https://doi.org/10.31235/OSF.IO/AHU8B.

Yunus, Raharjo, S., Handayani, M., Arifah, N., Rafli, Sitepu, N., Saleha, I. (2021). Peran Media Sosial di Era Transformasi Digital sebagai Sarana Komunikasi Karang Taruna Masyarakat Kampung Parung Serab Ciledug. Jurnal Abdimas Indonesia, 1(2), 40-46. https://doi.org/10.53769/jai.v1i2.71.

Zaoui, Fadwa, \& Souissi., N. (2020). Roadmap for Digital Transformation: A Literature Review. In Procedia Computer Science, Elsevier B., 5(6), 21-28. https://doi.org/10.1016/j.procs.2020.07 .090. 